SHS Web of Conferences 12, 01014 (2014)

DOI: $10.1051 /$ shsconf/ 20141201014

C) Owned by the authors, published by EDP Sciences, 2014

\title{
Cave Tourism: The Potential of Asar Cave as a Natural Tourism Asset at Lenggong Valley, Perak
}

\author{
Main Rindam ${ }^{1}$ \\ ${ }^{1}$ Centre for Distance Education, Universiti Sains Malaysia, 11800 Penang, Malaysia
}

\begin{abstract}
The Lenggong Valley, from a standpoint of natural tourism research, presents strengths, weaknesses, opportunities and challenges that can be utilized to help increase the opportunities for the local community to increase their standard of living. Asar Cave comprises one of the caves that are found in Lenggong. A series of external studies have been done on Asar Cave in order to measure its potential for natural tourism in Lenggong. The objective of this study is to discuss caves as a natural resource that has great potential in the growth of the economy of the residents of the Lenggong Valley. Marketing caves as a source of nature tourism helps the government's achievements in National Key Result Areas, apart from being a form of environmental control as well as helping to increase awareness about environmental education, specifically those associated with caves. The research results find that SWOT analysis presents huge potential for caves to become a source of nature tourism development in Lenggong. Great potential can also be seen from a standpoint of increasing the standard of living of its residents through their involvement in the tourism sector based on local natural assets.
\end{abstract}

\section{Introduction}

Caves are a part of nature tourism, or "ecotourism", that is capable of attracting tourists [1] and it increases in popularity in Korea [2] and even in Vietnam [3]. Caves are important to the tourism industry because it develops rapidly in developing countries, where hundreds of caves every year are developed for that purpose [4]. It could be said that caves form a complex natural resource in the large-scale tourism trade of a particular country [5]. There are more than 5,000 tourist-friendly caves around the world currently, with 10 of them being significant caves. Cave tourism successfully pulls approximately 250 million tourists every year with an estimated expenditure of USD2 billion, apart from providing employment to 200,000 people and generating a total household income of USD100 million per year [4].

The opening of Gua Phong Nha-Khe Bang, Vietnam in 1990 for instance, can facilitate to diminish the rate of poverty in the local community [6]. Taking inspiration from this experience, many countries around the world have taken initiatives to develop the caves found amongst them to be raised as important tourism products, such as the case with Brazil [19], Russia [5], Indonesia [20] and Australia [21]. 
The awareness behind turning caves into a source of natural tourism reaches far past the borders of mere economics. Based on the development of Malaysia, it involves the National Key Result Areas (NKRAs) o the government which seek to improve the quality of life of the local citizenry, and empower both urban and rural population [7]. Although it connects itself to the issue of eradicating hardcore poverty which itself is related to the granting of aid by the Malaysian Welfare Department, the development of women entrepreneurs and encouraging prosperity within rural communities through the increasing of various local infrastructure, it does not necessarily have to be the metaphorical 'fish', but is necessarily more akin to the same metaphor's "fishing rod".

Sustainability is described as increasing the quality of life through the increase of entrepreneurial knowledge. It's respectively, development that improves the quality of human life while living within the carrying capacity of supporting ecosystems. Developing natural resources and assets is ultimately for the sake of the sustainability of their livelihoods. The anthropocentric view focuses on the sustainable welfare of human [22].

The specialness and uniqueness of a certain cave's landscape should be shared with the general public. It is unique because caves only present the frond portion or 'gate' of itself, while most of it remains hidden [8]. The perception of the cave as a dark and foreboding place needs to be changed because in reality it comprises a landscape that is beautiful and awe-inspiring [9].

The aim of this paper is to discuss caves as a natural resource that has huge potential in the growth of the economy of the inhabitants of the Lenggong Valley. Therefore, marketing caves as natural source of tourism is important in order to help the achievement of government NKRAs, as well to serve as environmental conservation and to increase awareness of environmental education that is relevant to caves. Secondly is to explain SWOT analysis and its link to cave tourism development program in Lenggong, Perak.

\section{Area Background}

Asar Cave is situated to the West of Kajang Cave. It has a geographic location of $5^{\circ} 07.53^{\prime}$ North and $100^{\circ} 58.82^{\prime}$ East. This cave is situated 78 meter above sea level. In order to get to Asar Cave, visitors must travel through Kajang Cave and use a footpath as soon as they exit from the Southern gate of the aforementioned cave. The small footpath that has been layered with wood was built in bridge-form in order to ease visitors that wish to visit Asar Cave, Puteri Cave and Ngaum Cave. Moreover, this path forms a physical border between a rubber plantation and the foothills of a karst landforms that forms a complex of combined limestone caves in Lenggong, Perak.

The landscape of Asar Cave has one main gate that faces the South exactly in front of the Information Booth of the said cave, which was built by the Museum And Lenggong Heritage Authority. Visitors to Asar Cave will pass past many vents which can be entered through a variety of direction, including from the top of the cave. The inner land scape of Asar Cave is not like Kajang Cave, because it only has one main chamber and possesses a high ceiling at its Southern gate and tapers or lowers towards its Northern side. There are several vents in the East ceiling and wall of Asar Cave, but its opening is not very large. The interesting aspect of these vents is that they serve as passages that allow sunlight to enter into Asar Cave, which gives an artistic impact that is quite attractive.

Asar Cave possesses only one space or main hall. The ceiling for this space possesses many stalactites, and has no stalagmites. The stalactites of Asar Cave are unique in that their shape is sharp like the tooth of a shark (shark tooth stalactite). This fact shows that Asar Cave is a younger cave when compared to Kajang Cave or Puteri Cave. The existence of 'soda straws' and 'flowstone' on the cave walls is a natural resource that can be marketed to tourists. There are two kinds of rock present, namely tufa and travertine. Tufa is formed through the precipitation of calsium carbonate and is porous, while travertine is formed through the deposition of calcium carbonate is one of the signs that might be on Gua Kajang [10]. 
The description of Asar Cave from a physical geography standpoint comprises something that is interesting to produce and write out, because it itself is a field that is still new in Malaysia, even though this field has been long well-researched at the global level. Papers on this cave are hoped to give information that can be shared with the local citizenry associated with Ansar Cave, and brings communities both local and foreign to come and get to know it more intimately. It comprises the caves that must be visited in Lenggong because of its location, which is in the middle of Kajang Cave, Ngaum Cave and Puteri Cave. Landscapes such as stalactites can be found on the ceiling of Asar Cave. It has a coarse shape and slightly different from the stalagmites that are created through the dripped water, undergoing a crystallization process.

According to the locals, several vents or exist found in Asar Cave connects the said with other caves in its vicinity. These passages form added value packages that can be marketed as a tourism product that is based on a natural resource. Asar cave are fragile and should be conserved. Since cave are delicate place and almost no mechanisms for repair any cracks, scratches or even name writen on the wall, do so will stay that way perhaps idenfinitely. Asar cave provide food and shalter for animals particulary poultry such as birds and bats. They are particulary vulnerable to human interference when they are hibernating, and when they are bringing up the young. The best practice when we visit them is stick to one trail to minimize damage to the floor and wall of the cave.

\section{The Potential of Asar Cave as a Tourism Attraction in Lenggong Valley, Perak}

Mammoth Cave National Park has successfully raked in USD62 million for its local community in the south of Kentucky, USA [11]. If Mammoth Cave can give such a positive impact to the local economy, there is no reason why Asar Cave and its network of caves in the Lenggong Valley should not as well. Although some would says the Mammoth cave may be inappropriate as the cave resources in Lenggong cannot be compered but don't look at physical assets instead of the way people manage this cave to attract tourist.

If doubts still linger as per Asar Cave's ability to lift the local economy because of its remote location, look no further than New Zealand, which benefited greatly through placing Waitomo Cave on the tourist map. Originating from a tiny village with only 307 inhabitants, through government efforts and collaboration with tourism agencies in the country, Waitomo Cave successfully pulls 500, 000 tourists from around the world every year [12]. A 40 minute experience through the 200 meter tunnel via the limestone complex can bring numerous benefits to the local economy and the New Zealand economy in general. Even though this cave is separated from mainstream tourism, it still manages to attract hundreds of thousands of tourists to visit it. Again, it's not about what Mammoth and Waitomo have, it more towards approach requires a strategy to promote nature just like Asar cave and the others caves in Lenggong as haritage tourism product.

Tourism based on caves or speleotourism form a new space that involves a varied spectrum for tourists in nature [13]. The landscape of the caves (speleothems) such as stalagmites, stalactites and various other formations have long since attracted the interest of tourists who come to experience the view of the limestone caves around the world, as early as the beginning of the $20^{\text {th }}$ Century, where caves have received more than 500,000 visitors every year [14]. This development as attracted the interest of many researchers who study the motivations that bring all these people to come and witness, and enjoy, the landscape of these caves.

According to Samuel et al. 2008, who have studied the characteristics of cave tourists, their motivations and identified them according to certain segments in Korea, one segment that is discussed is the desire to experience for themselves being in the environment of a cave itself. Paolo Forti [4] concludes that for a while now, caves have become the most important geological item to tourists and for about 20 years recently, their economic important has increased dramatically in Oman. 
Cave tourists around the world are encountering an evolution and transformation in the context of tourism destinations. The focus of tourism now emphasises the issue of how interactions between tourism organisations can act as mechanisms for tourism destination management by themselves. Taking the case of Asar Cave and the other caves in the Lenggong Valley, the Local Authorit must play a pro-active role in marketing these resources in a more effective and efficient manner. Aspects that must be emphasised include efforts to increase visitor flow, the number of visitors and their duration of stay in Lenggong.

Lenggong Valley, which is a world heritage area, can become a gateway to cave tourism that already exists in the valley, especially in Asar Cave. The Ipoh-Kuala Kangsar-Grik route is a communal route from the West Coast to the East Coast of Peninsula Malaysia, which can offer economic benefits to the local community. As many as 3,421 vehicles used this route every day on 2011 , or 1,248,665 vehicles a year [15]. If each vehicle carries with it an average of three people that spend an average of RM100 a day on lodging, food, petrol and other provisions, the potential for spending along this corridor is RM41,622,166 a year.

It seems the economic opportunity along the Ipoh-Kuala Kangsar-Grik route is hardly taken advantage of by the local community, especially in Lenggong. The potential for Asar Cave as a natural tourism resource in Lenggong must be motivated by taking cues from reports that state that in 2006, outdoor recreative activities were capable of generation USD730 billion for the US economy, and provided employment for 6.5 million people across the country. In this context, Lenggong must be more proactive in marketing its natural resources through various packages that can utilise collaborations with various tourism agencies.

Asar Cave if combine with other caves in Lenggong valley can also elevate its potential as a 'show cave' by giving focus to four primary areas, which are scientific research, art, technology and management. Scientific research has obviously been suggested and performed early on, which would be the first phases of aspects of hydrology, geography, biological sciences and earth sciences, which can used a platform to gather experts in these field to Lenggong to study Asar Cave as well as other caves in Lenggong Valley. The surface features of Lenggong can become a hub of cave research across the region, and even internationally. Artistry, if combined with other disciplines such as engineering can increase the potential of Ansar Cave in the tourism sector.

The artistic lighting in the cave can be used as a value added aspect in Asar Cave, as an information centre about natural caves, such as the case with Heinrich's Cave, Germany [16]. The combination of art, technology and hydrometeorology are necessary to control water, humidity and other environmental influences in the cave for the design of appropriate paths for creating an artistic landscape viewing angle for tourists. Effective and efficient management begins as early as the planning stage on paper until the phase of the project is completed. This includes managing and adding to already existing infrastructure that has already been created, such as pathways and wooden walkways, and information huts, managing it so that it is safe to us by tourists and capable of supporting the presence of many tourists at a time. The surveying of wooden paths and constructs based on wood must be done often because wood easily spoils in geographic locations that encounter heat and humidity throughout the ear. Furthermore, wood easily rots, apart from it being vulnerable to termite attacks (Coptotermes formosanus).

When the Perak state government targets six million tourists in conjunction with Visit Perak Year 2014, the Lenggong Valley must acquire some benefit from this campaign [17]. In 2012, Lenggong was elevated to the status of tourism cluster in conjunction with Visit Perak Year (Tahun Melawat Perak, TMP) and was apropos with the concept of clusters itself, which meant fusing things together, and thi placing it among 10 tourism icons of Perak, under the Belum Royal State Park pakej, itself in Hulu Perak, making it relevant. The Visit Perak Year 2014 campaign and Visit Malaysia Year (TMM, Tahun Melawat Malaysia) 2014 need to include Lenggong as a destination or a tourism map, be it for state or country because it is a world heritage site.

Learning from experiences with spectacular cave like Mulu cave in Sarawak, Asar Cave and other caves in Lenggong are indeed unique and can be offered to the tourism industry in Perak as well as Malaysia in general. Taking the Blue Ocean strategy concept, which is to say "competition is no 
longer relevant", the uniqueness of the caves that are in Hulu Perak, $60 \mathrm{~km}$ from Ipoh city and 5 kilometres from the town of Lenggong, Asar Cave and the other caves around it can be considered caves with great geological wonders because it has stalactites, stalagmites and flowstones as well as landscape walls, and cave ceilings that are interesting to watch.

Asar Cave has a landscape that makes it well suited as a shelter because it has a main chamber that is wide, but is generally unsuitable as a domicle because its ceiling has numerous vents. These physical characteristics allow Asar Cave to offer tourist activities that are more challenging, such as crystal calcite exploring, exploring the vents on the ceilings and the passages that connect Asar Cave to the other caves in the karst area in Lenggong Valley (which takes around 30 to 40 minutes). Through this package, tourists can enjoy the atmosphere, the stone chamber, with wild plants and the calls of various unique animals.

Turning Asar Cave into a show cave for visitors or tourists is bound to open up opportunities for venturing into areas that before this were unavailable to the general public, for going into the caves that has been acclaimed as a form heritage with evidence of limestone formations that have been found. At this point, there are no archaeological digs that have been recorded at Asar Cave. Information about with Asar Cave must still be deepened and expanded. With that in mind, Asar Cave should be preserved as an educational too and could turn out to be a health development in the natural tourism agency. The cave environment should be developed as an ethnopark [5] which should focus on the local community economy, exotic animals, wells, the farming of maze and orchards, apart from fishing activities in rivers and lakes. It is best offered as a package and not separately.

The SWOT analysis was conducted in Lenggong valley in Mac, 2014. The purpose of analysis is to be used for Asar cave self evaluation. It's a lens under which tourism program can reflect on what is currenlyt working, not working and what obstacles might occor down the pipeline, to focus on what is positive and what needs to and can be inprove upon. The analysis has been conducted individually through three step. First step is scanning which start from develop a list, long or short of strengths of Asar cave, individually or as a group. Consider all elements of the cave and has been done on a flip chart. Second step was evaluate and consolidate by constructively read throug the list and eliminate any item that are redundant.

Boil down the top concept and summarize any item that are overly wordly. Choose the best 5-10 strengths that be the top strength, weakness, opportunity and threats or chalanges. The SWOT/C analysis of Asar Cave shows that this cave has Strength (S), Weakness (W), development opportunity (O) and threats $(\mathrm{T})$ or challenges $(\mathrm{C})$ that must be observed. Conceptually, strength (S) and weakness (W) are internal factors while the items of opportunity $(\mathrm{O})$ and threats $(\mathrm{T})$ or challenges $(\mathrm{C})$ on the other hand are external factors, as mentioned in Table 1.

Asar Cave and other caves in the Lenggong Valley have many strengths for fortifying their potential in the tourism industry, like S1- Ease of visit, S2- Having a protected environment, S3- That the heritage caves are under Lenggong Museum \& Heritage, and PBT, S4-Being an archaeological site S5 - Scientific value (geography, geomorphology, hydrology, speleology, karstology, biospeleology, ecology, palaeontology and archaeology. In lieu of that, the local community, especially the youth and women entrepreneurs in Lenggong, must take advantage of whatever opportunities that are present in order to realize the NKRAs targeted by the government. At the same time, efforts must be made in order to overcome problems with the present weaknesses, which are W1- Weak or poor marketing, W1- Threats to the cave ecosystem, W3-Imbalanced development in the district and W4-A lack of both amenities and services.

Collaboration with various government agencies such as the PBT, the District Council and private companies are very much needed in order to achieve this objective. Entities that have the stout ability to overcome these present weaknesses include the people of the Lenggong Museum and Heritage that was formed in 2012. It was aided by the Local Authorities (Pihak Berkuasa Tempatan, $P B T)$ as well as NGOs, and these groups include local farmers, tourism entrepreneurs and other members of society. 
Table 1. Formatting sections, subsections and subsubsections SWOT analysis.

\begin{tabular}{|c|c|}
\hline Strength (S) & Weakness (W) \\
\hline $\begin{array}{l}\text { S1 - Easy to visit } \\
\text { S2 - Protected environment } \\
\text { S3 - Heritage caves under Lenggong museum \& } \\
\text { Heritage and PBT. } \\
\text { S4 - An archaelogical site } \\
\text { S5 - Scientific value (geography, } \\
\text { geomorphology, hidrology, speleology, } \\
\text { karstology, biospeleology, ecology, } \\
\text { palaeontology dan archaeology). }\end{array}$ & $\begin{array}{l}\text { W1- Weak marketing } \\
\text { W2 - threat to the cave ecosystems } \\
\text { W3- Uneven development in the district } \\
\text { W4- A lack of relevant amenities and services }\end{array}$ \\
\hline Oppertunity (O) & Threats (T)/challenges (C) \\
\hline $\begin{array}{l}\text { O1. A focused strategy in developing the specific } \\
\text { needs of tourism } \\
\text { O2. An oppertunity to upgrade tourism resources } \\
\text { already available } \\
\text { O3. Operational all-year round } \\
\text { O4. The mastery over a new market } \\
\text { O5. New job oppertunities in local community } \\
\text { O6. The strengthening of the entrepreneurial field } \\
\text { O7. Insentives to develop new forms of special } \\
\text { tourism interests }\end{array}$ & $\begin{array}{l}\text { T/C1. Competition from the international market } \\
\text { T/C2. A lack of investor interest } \\
\text { T/C3. A lack of initiative by the locals } \\
\text { T/C4. Few locals } \\
\text { T/C5. No control or protection to archeological } \\
\text { sites and formasions of dripstones. }\end{array}$ \\
\hline
\end{tabular}

The various opportunities that are predicted to arise can sustain and elevate the number of visitations and total amount of visitors as well as protect the ecosystem of Asar Cave and the various other caves that are found within the karst complex from non-sustainable management practices. With the presence of various opportunities, such as O1-A focuses strategy in developing the specific demands of tourism, O2- The opportunity to upgrade present tourism resources, o3-Year-long operation, O4- The mastery of a new market, O5-New job opportunities for the local community, O6The strengthening of the entrepreneurial field and O7- Incentives to develop new forms of special interests in tourism. The local community are not able to interpret all opportunities available to opportunities specifically for increasing their standard of living without help from the PBT and the relevant authorities. At the same time, the aspect of threats $(\mathrm{T})$ or challenges $(\mathrm{C})$ need to have their impacts lessened to the local community. Although there is some concern over the negative impact of tourism on the environment of the cave, studies have shown that such concerns are largely unsubstantiated because the ambient heat that is produced by visiting tourists is quickly absorbed into the caves cavernous chamber [18]. This issue came about based on a report done on a research side in the heritage site of Phong Nha-Khe Bang cave in Vietnam, which also presents that the stalactites within the cave lost their colours and showed signs of dryness and mould[6]. Threats like T/C1Competition from international markets, T/C2- A lack of investor interest, T/C3- A lack of initiative among the local community, T/C4- A small population and T/C5- No control or protection to archaeological sites and dripstone formations. The environment of a cave is dark, cold, damp and the ability to manage risky as well as dangerous situations require well-developed standard guidelines in order to ensure that the safety of the tourists is guaranteed. The PBT of the Lenggong Valley must learn from premier organisations around the world, especially in structuring tourism experiences that are challenging. Cooperation with organisations that have a great deal of experience involving rugged or challenging activities is sorely needed, especially in the form of quality training programs that follow international standards. At the same time, a formal mechanism must be present in order to 
satisfy the need for a 'rescue team'. Guides from exploration organisations work together in emergency situations. The question that often arises is what happens when cave tourists are faced with emergency situations. Interaction among the members of these networks is extremely critical in order to give rise to working relationships that are based on knowledge when they acknowledge their mutual co-dependence, which they both feel towards the reputation towards a particular tourist destination. The development of this capability only exists when the network is formed and interaction begins to form acknowledgement based on knowledge in an outer context.

Enabling the marketing of the caves of the Lenggong Valley is sorely needed. Market competition such as Red Ocean strategies does not suffice for Asar Cave, when compared to using a Blue Ocean strategy that places competition as irrelevant. In lieu of that, Asar Cave needs initiate a four-grid framework in order to demonstrate its presence in the nature tourism product market, via four elements, which are eliminate, reduce, raise and create.

In order to increase its potential as a tourism product, the element of weakness (W) must be eliminated; the element of strength (S) must be expanded just like how the development of the cave follows international standards in the field of tourism cave management by involving researchers (in the fields of karstospeleolog, geography, geology, archaeology, palaeontology, earth sciences, endokarst biology, vegetation, economy, karst area conservation and art), identifying the value added aspects of a cave, such as measuring the dynamics of the cave, planning the circulation of visitors and access, determining the required funding, planning a marketing strategy, identifying the cave's biota, its microbiota and its macro-ecosystem of flying cave dwellers, the mapping of the cave system, examining the quality and quantity of fresh air that is required and determining zoning when there arises a need to close a section of the cave for the purposes of academic research.

The potential of Asar Cave can also be expanded through the element of creation, especially using the aspects of opportunity $(\mathrm{O})$ that are available for creating new demands within the tourism industry. Creativity and innovation must be adapted in order to enrich Asar Cave (in the form of products, services and presentation). Creativity in the form of interactivity, for example, seeks to see marketing groups that are structured into three groups, the first group being local stakeholders, where the focus of this group is to penetrate the local supply chain. Secondly, cooperation with tourism agencies can bring benefits to Asar Cave, and thirdly, with tourism agencies that have a dominant presence in the national tourism industry, such as a relationship with Malaysian Airlines (MAS), Berjaya Air, Firefly, Malindo Air and AirAsia as icons that have a direct relationship with good tourists from within and outside the country.

\section{Conclusion}

The main goal of this paper is the spread the knowledge about the uniqueness of the caves of the Lenggong Valley, especially Asar Cave, to the local community and also to international tourists. These special qualities, or uniqueness, become the basis to Asar Caves potential as a natural asset to be elevated as a major destination in the tourism agency. This effort is tightly tied to the desire to initiate the NKRA requirements for increasing the quality of life of low income groups and also through the empowerment of infrastructure in the rural areas. As such, the local community must involve themselves directly with ecotourism not just for increasing their income but also for doing rehabilitation work. Secondly, it is hoped that with this paper, it will increase public awareness about how important it is to preserve environmental heritage, especially the caves in this valley, so that they can persist as an abundant resource for the future generations of Lenggong. Considering the competition faced by tourism destinations that ever increase within the economy, both locally and globally, Asar Cave's potential as a natural tourism asset in Lenggong must be seen from an angle of its uniqueness. 


\section{Acknowledgment}

The authors wish to thank Universiti Sains Malaysia for the Research University Grant managed by the Sustainable Tourism Research Cluster (1001 / PTS / 8660012)

\section{References}

1. Zsuzsa Tolnay, Interpretation in Cave Tourism - A little utilised management tools", http://www.i-s-c-a.com/documentloader.php?id=663\&filename=35-tolnay-interpretation-incave-tourism.pdf. Cited at 5 November (2013).

2. Seongseop Samuel Kim, Miju Kim, Jung Woong Park, Yingzhi Guo."Cave Tourism: Tourists' Characteristics, Motivations to Visit, and the Segmentation of Their Behavior". Asia Pacific Journal of Tourism Research.13:3, 299-318 (2008).

3. Pang Nguyen Hong, Quan Dao Thi, Quynh Le Kim Thoa. Ecotourism in Vietnam: Potential and reality. Featured in October (2012) http://kyotoreview.cseas.kyotou.ac.jp/issue/issue1/article_167.html. Cited at January 16, 2014.

4. Paolo Forti. "Caves: The most important features geotouristic in the world", 3rd International Conference on Geotourism. (2013)

http://www.geotourism.om/geo/presentation/2\%20Paolo\%20forti\%20Geoparchicarsici.pdf Cited at 5 November 2013.

5. Knezevic \& Renata Zikovic Grbac, "Analysis of the condition and development of cave tourisn lucre in Primorsko-goranska Country", Turizm, 15: 1,11-25 (2011).

6. Thanhnien News. Com., "Researcer say tourism is ruining Vietnam's worl famous caves", Thanhnien News, 16 Dicember (2012).

http://www.thanhniennews.com/2010/pages/20121216-researchers-say-vietnam-grand-cavesneed-to-rest-from-tourism.aspx. Cited at 6 November 2013.

7. 1 Click. The success of the 2014 Six areas NKRA (2014). http://pmr.penerangan.gov.my/index.php/nkra/4808-pointers-6-bidang-keberhasilan-utamanegara-nkra.html. Cited at 8 January 2014.

8. Patricia Kambesis, "The Importance of cave exploration to scientific research", Journal of Caves and Karst Studies, 69: 1, 46-58 (2007).

9. Bahamas Caves Research Foundation, "Research and conservation of blue holes and flavor of the Bahamas" (2013). http://www.bahamascaves.com/. Cited at 6 November 2013.

10. Main Rindam, Fatimah Hassan, "The Potential of Lenggong Valley as a Natural Tourism Resources in a Rural Setting" viewed. Proceedings of the 3rd Regional Conference on Tourism Research, Bayview Hotel, Langkawi, Malaysia. October 29-31 (2013).

11. Vickie Carson, Mammorth cave pumps \$ 62 million/year into local economy. The Amplifier. (Thursday, February 23, 2012)

12. Kathryn Pavlovich."The evolution and transformation of a tourism destination network: the Waitomo Caves, New Zealand", Tourism Management, 24: 2, 203-216 (2013).

13. Heros Augusto Santos Lobo, Eleonora Trajanoc, Maurício Marinho de Alcântara, Maria Elina Bichuettee, José Antonio Basso Scaleante, Oscarlina Aparecida Furquim Scaleantef, Bárbara Nazaré Rocha, Francisco Villela Laterza."Projection scenarios onto fragility of tourist maps: Framework for determination of provisional tourist Carrying capacity in a Brazilian show cave". Tourism Management, 35, 234-243 (2009).

14. A. Baker, D. Genty. Journal of Environmental Management, 53(3), 165-175 (1998)

15. Ministry of Transport Malaysia. 2012 Transport Statistics 2011 http://www.mot.gov.my/my/Publication/Official/Statistik\%20Pengangkutan\%20Malaysia\%2 02011.pdf. Accessed on January 14, 2014.

16. Cave Lighting. Light up your show cave. Made by cave lighting: Heinrich's cave. http://www.cavelighting.com/index.php?area=1. (2014) Cited at January 13, 2014. 
17. Silver News. "Silver target of 6 million tourists for 2014" in the. Silver News, 10 September 12:15 Tuesday (2013). http://www.peraknews.com/berita-utama/49-utama/9689-silvertarget-6-million-visitors-to-2014. Cited at 7 November 2013.

18. Science Daily, "Tourist does not harm all caves, study suggest”, Science Daily, 11 April. (2011). http://www.sciencedaily.com/releases/2011/04/110411111036.htm. Cited at 6 November 2013.

19. Heros Augusto Santos Lobo \& Edvaldo Cesar Moretti. "Tourism in Caves and the Conservation of the Speleological Heritage: The case of Serra da Bodoquena (Mato Grosso do Sul State, Brazil)". Acta Carsologica 38/2-3, 265-276, POSTOJNA (2009).

20. Eva Rachmawati \& Arzyana Sunkar. "Consumer-Based Cave Travel and Tourism Market Characteristic in West Java, Indonesia". Tourism and Karst Areas, 6(1), (2013).

21. Dragovich, D. \& Grose, J. "Impact of tourists on carbon dioxide levels at Jenolan Caves, Australia: an examination of microclimatic constraints on tourist cave management". Geoforum, Vol. 21(1), 111-120 (1990).

22. Barret, C.B \& R.E. Grizzle. "A holistic approach to sustainability based on pluralistic stepwardship ". Environmental Ethics. 21 :23-42. 